Article

\title{
The Unique Sacrifice of Christ According to Hebrews 9: A Study in Theological Creativity
}

\author{
Christian A. Eberhart ${ }^{1}$ (1) and Donald Schweitzer ${ }^{2, *}$ \\ 1 Department of Comparative Cultural Studies, Religious Studies Program, University of Houston, Houston, \\ TX 77204-5020, USA; ceberhart@uh.edu \\ 2 St. Andrew's College, Saskatoon, SK S7N 0W3, Canada \\ * Correspondence: don.schweitzer@usask.ca
}

Received: 6 November 2018; Accepted: 9 January 2019; Published: 12 January 2019

\begin{abstract}
The letter to the Hebrews develops a distinct christological and soteriological concept of Jesus as both high priest and unique sacrifice once and for all. In doing so, Hebrews remains largely faithful to cult traditions of Second Temple Judaism. Especially the concept of Jesus as sacrifice is, however, theologically creative and innovative. The present essay explores these dynamic developments and discusses how they led early Christianity to ultimately abandon the temple cult.
\end{abstract}

Keywords: Jesus; Christology; soteriology; sacrifice; creativity; metaphor; Second Temple Judaism; early Christianity; letter to the Hebrews

"... surely the work of an Amos or a Paul, of an Augustine or a Luther must be regarded as contributing to the construction or reconstruction of the notion of God." ${ }^{1}$

The letter to the Hebrews represents a distinctive voice within the New Testament. It is the work of a great and original theologian. The understanding of the death of Jesus in Hebrews 9 has been described as "one of the most theologically creative arguments of the New Testament." ${ }^{2}$ Here central parts of the religious heritage of Second Temple Judaism are taken up in light of faith in Jesus Christ in a way that re-configures both. The result is a startlingly original interpretation of the nature and significance of Jesus' death that uses themes and practices of Jewish temple worship metaphorically to argue for the uniqueness of Jesus' saving significance. This contributed to a revolution in ancient religious thought and practice that occurred in early Christianity: the renunciation in principle of sacrifice. ${ }^{3}$ Hitherto it had largely been axiomatic in ancient religions that the divine was worshipped through offering sacrifices. The early church ceased to do this. This extended a development already underway within Judaism. Other Jewish groups at this time were already distancing themselves from sacrificial worship, but none renounced it in principle. ${ }^{4}$ This renunciation did not happen all at once. After Jesus' death, Jewish Christians continued to participate in Jewish sacrificial worship. Contingent events like the destruction of the temple contributed to this renunciation, but they alone do not explain the theological argument for ceasing to offer sacrifices. ${ }^{5}$ According to the New Testament,

\footnotetext{
(Kaufman 1979, p. 35).

(Matera 2007, p. 341).

(Theissen 1999, p. 139).

(Ibid., p. 140). As Theissen notes, while the Essenes did not participate in sacrificial worship, they did not renounce it in principle. While other Jewish groups ceased to offer sacrifices after the destruction of the temple, they continued to study and expound the sacrificial laws, even though these could no longer be practiced. What is distinctive in Hebrews 9 is the renunciation of sacrifice in principle (ibid., pp. 140-41).

5 (Ibid., pp. 140-42).
} 
this renunciation of sacrifice was bound up with the interpretation of Jesus' death as sacrificial. ${ }^{6}$ A theological argument for the renunciation of sacrifice in principle first appears in Christian circles in Hebrews 9.7 This chapter features a new discourse about sacrifice, arguing that the unique sacrifice of Jesus makes all others redundant.

Theological creativity is essential to the life of the church. The understandings of the faith of the past, while informing those of the present, cannot simply be repeated over and over again. Time tends to move towards what is relatively new and unique, even as history seems to repeat itself. Understandings of the faith from the past need to be re-thought in order to relate to what is relatively new. If the church proclaims an understanding of the gospel from another time or place that is not appropriate to its context, it may represent a flight from reality and become a counter-sign to the gospel by refusing to address the sin and evil of the present. ${ }^{8}$ George Lindbeck famously described the task of Christian theology as re-describing "reality within the scriptural framework." ${ }^{9}$ But the struggle of Western churches to come to terms with the Holocaust is one example of how the theological task is often more dialectical than this. Coming to terms with the Holocaust was a learning process for many Western Christian theologians, through which they learned of the need to correct the negations of Jewish existence that had been repeated for centuries in church teachings ${ }^{10}$ and to recognize that distorted representations of Judaism were present within the New Testament itself. Coming to terms with the Holocaust is an example of how relatively new events can require theological creativity on the part of the church.

The impetus for theological creativity also lies in the roots of Christian identity itself. While past understandings of the faith may be normative, they are themselves fragmentary, sometimes flawed, and always in need of interpretation. In the Bible's history of promises of future salvation, in the eschatological outlook that permeates much of the New Testament, there is a drive towards what is new as well. This includes a drive towards new understandings of Jesus Christ and his saving significance. There is always more in the gospel than any theology has expressed. Thus, the impetus for theological creativity comes from the transcendence of the gospel message, from faithfulness to the biblical witness and the Christian tradition, as well as from time's movement towards what is relatively new.

Yet while theological creativity understands the Christian faith in new ways, in relation to new knowledge or new forms of thought and experience, it must also be faithful to its past, to its sources in the biblical witness and Christian tradition. Theological creativity has to maintain the identity of the Christian faith, even while it may transform it. Otherwise it falls into self-contradiction, conflicting with what it claims to be based upon. The letter to the Hebrews described Jesus in a new way while remaining largely faithful to its sources. It presents an understanding of Jesus Christ and his saving significance that is both theologically creative and traditional. ${ }^{11}$ Martin Luther praised it for the understanding of Christ's priesthood that it built on the "foundation of faith," the confession of Jesus as crucified and risen. ${ }^{12}$ How did it build on this?

What follows will study the understanding of Jesus' death in Hebrews 9 as an example of theological creativity. We will look at how this understanding was creative and what can be learned from it about theological creativity. But first we must ask, what is Hebrews? Where did it come from and why was it written? What is the place of Hebrews 9 in its argument?

The introductory matters of the letter to the Hebrews are among the most disputed within the entire New Testament, which is why this text remains notoriously enigmatic to this day. For many

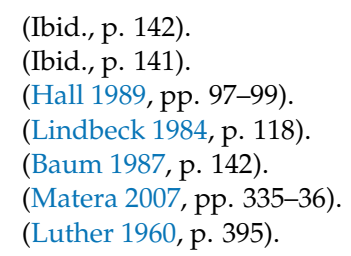


centuries, church fathers and exegetical scholars alike have wondered who wrote it when, where, and to whom. A consensus is barely in sight. In addition, even its literary structure is somewhat unclear. The following is an attempt to provide a short overview of the status quaestionis.

Where did Hebrews come from? This question is not easy to answer because nowhere does it feature the name of an author. Hebrews has nevertheless been considered a Pauline letter throughout much of the history of biblical interpretation; Paul, however, typically starts his letters by following the standard epistolary pattern of antiquity, thus mentioning himself as author (e.g., Gal 1:1; Rom 1:1) and occasionally his travel companions as well (1 Thess 1:1: Silvanus, and Timothy; 1 Cor 1:1: Sosthenes; 2 Cor 1:1; Phil 1:1: Timothy). In addition, both the distinct vocabulary, the style, and the theology of Hebrews are quite different from their respective counterparts in Paul's authentic writings. ${ }^{13}$ It is unlikely, therefore, that Paul could have penned Hebrews. Intermittently, some of Paul's travel companions have been considered instead, such as the highly educated and eloquent Apollos from Alexandria. ${ }^{14}$ However, none of these proposals have been widely accepted in modern biblical scholarship. While it is and will remain difficult to determine the authorship of Hebrews with certainty, an interesting hypothesis was made more than a century ago by Adolf von Harnack (and has recently been adopted by others, for example by Mary Ann Beavis and HyeRan Kim-Cragg). Von Harnack argued on stylistic grounds that Hebrews has more than one author, and that they could be Priscilla/Prisca and her husband Aquila. ${ }^{15}$ The latter is known as Paul's fellow tentmaker. ${ }^{16}$ An interesting aspect of this proposal is that it assumes the active involvement of a woman, which would have discredited this writing in antiquity. It therefore provides a potential rational for the anonymity of Hebrews. However, one sentence in Heb 11:32 features the masculine singular participle form $\delta \imath \gamma \gamma$ this theory questionable. ${ }^{17}$ Hence, most scholars conclude that the author(s) of this anonymous book remain(s) unknown; in so doing, some repeat the famous statement by the Hellenistic scholar and early Christian theologian Origen of Alexandria (ca. 184-ca. 253 C.E.) that only God truly knows who wrote Hebrews. ${ }^{18}$

More can be said about the characteristics of language and argumentative patterns. Craig Koester shows that Hebrews features a variety of aspects that are typical of different Jewish groups of the 1st century C.E. He concludes, however, that it originated primarily in a milieu of Hellenistic Judaism and notes similarities to Philo's writings. The text was very popular in Lower Egypt, specifically in the city of Alexandria, which was a center of Hellenism in the Mediterranean world and the home of Philo. ${ }^{19}$ The anonymous author(s) of Hebrews was (were) skilled in the tradition of Jewish or Jewish-Christian argumentation, as Wolfgang Kraus suggests. ${ }^{20}$ Along with these ideas, the date of composition of this writing has been narrowed down to the second half of the 1st century C.E. Parallels to First Clement are of importance as terminus ante quem, yet the dating of that writing remains uncertain in its own right. ${ }^{21}$

Even the literary structure and main argument of Hebrews are not easy to determine and have been the subject of ongoing scholarly debate. For example, Susan Docherty recently noted:

13 Cf. (Koester 2001, p. 43; Karrer 2002, pp. 35-39; Eisenbaum 2005, p. 220; Rothschild 2009, pp. 45-62).

14 Cf. (Koester 2001, p. 44; Beavis and Kim-Cragg 2015, p. lix). The eloquence of Apollos and his knowledge of scriptures are mentioned in Acts 18:24; Paul, on the other hand, admits freely that he did not rely on rhetorical skills (1 Cor 2:1-5). This could have been the reason for factions in the congregation of Corinth (1 Cor 1:12; 3:4-5). Recently, Clare K. Rothschild has suggested that Hebrews might be a Pauline pseudepigraphon (Rothschild 2009, pp. 1-14).

15 Cf. (von Harnack 1900), referenced recently in (Beavis and Kim-Cragg 2015, pp. lix-lx).

16 Cf. (Koester 2001, p. 45).

17 Cf. (ibid., p. 45; Karrer 2002, p. 32; Eisenbaum 2005, p. 218; Koosed and Seesengood 2005, pp. 276-77).

18 Cf. (Beavis and Kim-Cragg 2015, p. lviii).

19 Cf. (Koester 2001, p. 59).

20 "Es muss sich beim Autor um jemanden handeln, der nicht nur in der jüdischen oder judenchristlichen Tradition bewandert ist, sondern der zu argumentieren gelernt hat, wie es im antiken Judentum üblich war" (Kraus 2017, p. 293). See also (Schnelle 2015, pp. 378-82).

21 Cf. (Attridge 1989, pp. 6-9; Koester 2001, pp. 50-54; Karrer 2015, p. 681; Ullucci 2012, p. 90; Beavis and Kim-Cragg 2015, pp. lxii-lxiv). 
"Commentators in every era have struggled to make sense of the overarching argument of Hebrews." 22 Perhaps this is a statement that can be connected to the above-mentioned hypothesis of collective authorship. Nevertheless, Hebrews itself gives a clue as to what it is about when it introduces chapter 8 as its "main point" ( $\kappa \varepsilon \varphi \alpha ́ \lambda \alpha\llcorner o v, 8: 1$ ), which deals with Jesus as the new high priest at the heavenly

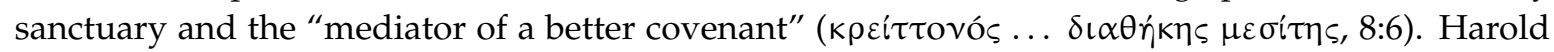
Attridge recognizes this verse as the start of the "heart of the christological exposition of Hebrews," comprising 8:1-10:18. ${ }^{23}$ These chapters display a creative and unique combination of the image of Jesus as high priest and sacrificial offering at the same time:

8:1-2: Jesus is high priest at the heavenly sanctuary;

8:3-5: The earthly antitype: high priests offer sacrifices at a "shadow" sanctuary of the heavenly one;

8:6: Jesus "obtained a more excellent ministry" and "is the mediator of a better covenant";

8:7-13: A quote from Jer 38:31-34 LXX about the "new covenant" serves as proof that the old covenant has become obsolete;

9:1-5: A description of the earthly sanctuary, the tabernacle;

9:6-10: Rituals at the Day of Atonement, which serve as "symbol/parable" $\left(\pi \alpha \rho \alpha \beta o \lambda \eta^{\prime}\right)$ for the present time;

9:11-15: Christ is both high priest and sacrifice; his "blood" ( $\alpha i ّ \alpha \alpha)$ purifies our conscience;

9:16-17: Explanation (excursus): in a testament, the heirs can claim the inheritance upon the death of the testator;

9:18-22: Blood and covenant;

9:23-28: Christ entered heaven and, through his own sacrifice, removed sin.

These two chapters are followed by a hortatory section calling the audience to persist in the faith of past heroes (Heb 10:19-11:40). In fact, Hebrews in its entirety alternates between sections of doctrinal exposition and exhortation. ${ }^{24}$

Chapter 9 is part of this central christological exposition of Hebrews. And while little is known about its author(s), it appears to have addressed Christians of a Hellenistic/Jewish background who, from the author's/authors' point of view, were in danger of lapsing from faith in Christ and reverting to their previous religious practices. ${ }^{25}$ How does Hebrews 9 interpret Jesus as the Christ in relation to this context so as to prevent this? What traditions and concepts does it draw upon to describe Jesus' person and saving significance? What guides and shapes the way these are employed? What is creative about the understanding of Jesus presented here?

These questions lead us to the exploration of the characteristic christological and soteriological profile of Hebrews, especially its cultic theology. Our chapter Hebrews 9 interprets Jesus as the Christ by presenting him as "a high priest of the upcoming good things" ( $\alpha \rho \chi \varepsilon \rho \varepsilon \dot{\cup} \varsigma \tau \widetilde{\omega} v \gamma \varepsilon \vee 0 \mu \varepsilon$ v $v \omega v$ $\dot{\alpha} \gamma \alpha \theta \widetilde{\omega} v$, Heb 9:11). This topic, however, permeates several chapters of Hebrews; the high priestly role of Jesus is first explicitly mentioned ${ }^{26}$ in Heb 2:17: "Hence he had to become like his brothers in every respect, so that he might be a compassionate and faithful high priest (i $v \alpha \dot{\varepsilon} \lambda \varepsilon \dot{\eta} \mu \omega \nu \gamma \varepsilon \dot{\varepsilon} \eta \eta \tau \iota k \alpha i$ $\pi\llcorner\sigma \tau \grave{s} \varsigma \dot{\alpha} \rho \chi \varepsilon \rho \varepsilon \dot{u} \varsigma)$ in the service of God, to obtain atonement for the sins of the people." From there on, it is being developed against the antitype of the Levitical priesthood-which consists of many priests (7:23) who had to offer sacrifices also for their own sins (5:1-4) - and according to the type of the

\footnotetext{
(Docherty 2016, p. 386).

(Attridge 1989, p. 216).

Cf. (Beavis and Kim-Cragg 2015, pp. lxxi-1xxii).

(Marshall 2009, pp. 267 n42, 276).

The distinction between "explicitly" mentioning the role of Jesus as high priest and an implicit reference is due to the fact that already the opening statement of Hebrews, which lists "purification for sins" as well as sitting "at the right hand" of God in heaven as achievements of Jesus (Heb 1:3), could be interpreted as hints to his high priestly role (8:1).
} 
priesthood of Melchizedek (7:1-3, 6), which is introduced in its own right as antitype to the Levitical priesthood (7:11). The high priesthood of Jesus, therefore, is now postulated alongside his being an "apostle" (3:1); Jesus is a special, i.e., "great" high priest because, having been tempted himself, he is able to understand human weaknesses (4:14-15); he was directly appointed by God (5:5) through an oath (7:20-22) according to the order of Melchizedek (5:6, 10; 6:20; 7:15-17). Being a holy, blameless, and perfect high priest (7:26-28), Jesus is seated at the right hand of God and ministers at the true, heavenly sanctuary $(8: 1)$. With this wide range of attributes, the high priesthood of Jesus clearly supersedes the traditional, Levitical priesthood and appears to be a climactic aspect of the Christology in Hebrews. ${ }^{27}$ It is, however, rather a precursor to the distinct christological and soteriological concept of Jesus as perfect and unique sacrifice. Although somewhat paradoxical, Hebrews depicts Jesus Christ indeed as both priest and sacrifice. The combination of these two images can be seen as an exercise in theological creativity, and this is especially true of the way in which Hebrews employs the concept of sacrifice and develops it further.

In order to apply sacrificial metaphors christologically, ${ }^{28}$ chapter 9 first provides the audience/ readers with a description of the earthly sanctuary, namely the tabernacle (vv. 1-5); second, it outlines priestly duties during the Day of Atonement ceremony, which includes the offering of burnt offerings and sin offerings (vv. 6-10). Both sections are remarkable as they suggest a time of composition of Hebrews after the destruction of the Second Temple in Jerusalem. ${ }^{29}$ Having set the stage and introduced the appropriate traditional Jewish festival, Hebrews now argues: "But when Christ came as a high priest of the upcoming good things, then through the greater and perfect tent (not made with hands, that is, not of this creation), he entered once for all into the sanctuary, not with the blood of goats

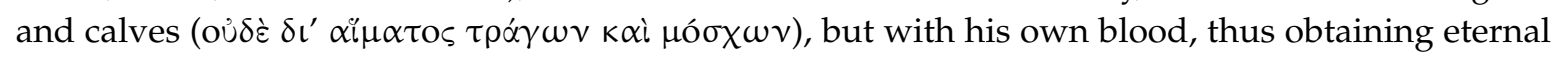

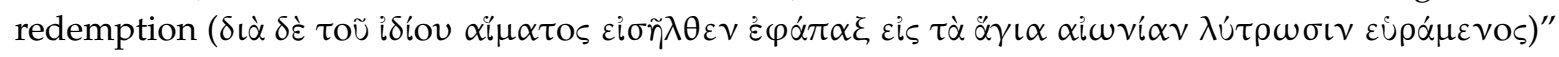

27 This short contribution cannot explore in detail that the attribution of the high priestly role to Jesus remains somewhat enigmatic and is barely based on historical facts since the New Testament Gospels do not depict him as a priest. On this problem, see for example (Weiss 1991, pp. 228-37; Frey 2018, p. 114). Mary Ann Beavis and HyeRan Kim-Cragg note on this aspect: "The image of Christ's Melchizedekian priesthood and the comparison of Christ to the high priest provide a model of ministry that transcends criteria of race, class, and gender and raises questions about the ecclesiastical propagation of priestly castes" (Beavis and Kim-Cragg 2015, p. xliv).

28 A comprehensive discussion of the broad topic of metaphor theory is impossible due to the limited scope of the present essay. We would nevertheless like to briefly point out that the term "metaphor" is derived from the noun $\mu \varepsilon \tau \alpha \varphi \rho \rho \alpha$, which literally means "transfer" and has already been used in antiquity to designate figurative language or semantic innovation, whereby aspects of one referent are 'transferred' to another (Aristoteles, Rhetoric 1411b; Poetic 1457b; see also (Eco 1984, p. 102; Berger 1988, p. 344; Zimmermann 2003, p. 7)). According to this definition, hyperbole, metonymy, and simile are all types of metaphor. By contrast, not every attempt of speaking about events in the past (historical facts) or present would be considered metaphorical language. Furthermore, the fact that the act of speaking is separate from an event does not necessarily mean that speaking as such constitutes metaphorical language, even if every articulation of past or present events always involves and requires an act of interpretation by the speaker. In other words, the 'transfer' alone from a past or present event to the realm of speech, or the endeavor of its linguistic representation, is not the transfer that a metaphor usually designates. This means with regard to the language of sacrifice in the Hebrew Bible or New Testament that descriptive or prescriptive texts about sacrificial rituals such as those in Lev 1-7 or 16 do not feature metaphors; on the other hand, calling a person's "broken spirit" a "sacrifice" (Ps 51:19) or speaking of Jesus as an "offering and sacrifice

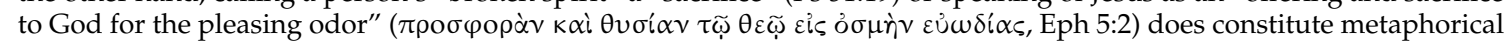
language. Considering, therefore, that Jesus was executed by crucifixion and not ritually slaughtered on an altar in front of a religious temple (cf. Karrer 2008, p. 153), it is impossible to claim "that the cultic language of Hebrews is not metaphorical" and that his death was a "real sacrifice" (Stegemann and Stegemann 2005, p. 18).

29 On scholarly hypotheses regarding the dating of Hebrews, see above. Had Hebrews been written before the destruction of the Second Temple in 70 C.E., then the precise description of the sanctuary and priestly duties during Jewish worship rituals in chapter 9 would have been superfluous as the audience/readers would have been familiar with both. After the destruction of King Herod's temple, however, such details would have started to fade from the collective memory. Furthermore, the peculiar circumstance that the author(s) of Hebrews preferred to evoke the tabernacle makes more sense post destruction. From this point in time forward, the temple in Jerusalem ceased to be the location of reference for sacrificial concepts and metaphors; it gradually came to be replaced by the sanctuary described in the Tora as Israel's portable "tent of meeting" (Exod 25-31, 35-40; cf. (Eberhart 2018, pp. 34-39)). It should be noted, however, that some aspects of the tabernacle featured in Heb 9:1-5 differ from its scriptural sources, for example the position of the golden altar of incense ( $\theta u \mu\llcorner\alpha \tau \dot{n} \rho\llcorner 0 v)$, which is located in the holy place according to Exod 30:1-6 but in the Holy of Holies according to Heb 9:4. For a comprehensive comparison, see (Thompson 2008, p. 178; Karrer 2002, pp. 143-44; Holtz 2011, pp. 366-67; Beavis and Kim-Cragg 2015, p. 91). 
(9:11-12). The question of which traditions and concepts were employed to describe Jesus' saving significance is answered here. Jews living during the Second Temple period would have known that blood application in the context of sacrificial rituals was a cultic means of obtaining atonement, and that it was the very special task of the high priest on the Day of Atonement (Lev 16:6, 15-19, 32-33). ${ }^{30}$ By contrast, the audience/readers of Hebrews living shortly after the conclusion of this period were being reminded of these matters. Hebrews 9 now argues that Jesus, the new high priest, brings sacrificial blood as well; yet he brings his own blood. This makes Jesus both high priest and sacrifice; it combines in him the role of the person traditionally in charge of performing atonement rituals with that of the animal that serves as the medium of atonement in so far as its blood is the very substance that is needed to perform these rituals. But Hebrews does not stay there; Hebrews employs poetic license in at least three instances. First, developing this concept further, Christ is said to have entered heaven and, through his own sacrifice that occurred only once, effectively removed sin for all times (9:23-28). ${ }^{31}$ Second, it has been observed that Hebrews leaves out chief components of the Day of Atonement ceremony such as the Azazel (or Scapegoat) ritual or the sevenfold sprinkling of sacrificial blood. Despite evoking the image of the tabernacle sanctuary in Heb 9:1-5, the sacrifice of Christ is rather described with reference to the Mosaic covenant ritual in Exod 24:8 that occurs before the tabernacle had been constructed (Heb 9:18-22). ${ }^{32}$ And third, as recently argued by David M. Moffitt, Hebrews maintains that the presentation of the blood of the sacrificial animals-understood here as their life-in the Holy of Holies is effectively associated with the atonement obtained on the Yom Kippur, just as the self-presentation of the resurrected Jesus before God in the heavenly sanctuary is connected with the new kind of atonement. ${ }^{33}$ Clearly, then, Hebrews has no problem joining aspects that are hard to combine, especially when they result in a new christological/soteriological concept.

Yet there is more to the creativeness of Hebrews than just the combination of somewhat heterogeneous images. A careful exploration of the way in which the metaphor of the sacrifice of Jesus is employed yields the result that it undergoes significant development and alteration. According to recent studies, the 'point' of sacrificial rituals in the Hebrew Bible is not killing. Instead, sacrifices are about approaching the sanctuary and ultimately God who resides there; this is what the Hebrew term for sacrifice, qorban, conveys. Within this context, blood application rites effect purification and atonement. ${ }^{34}$ Years before Hebrews was authored, Paul employed the term "sacrifice" metaphorically to convey the distinct quality of something, specifically that somebody or something, including spiritual actions, pleases God (Rom 12:1; Phil 4:18). Again, death or killing has no place in these images. Entirely in line with these metaphors, the author(s) of Hebrews initially mention(s) that "Jesus ... offered up

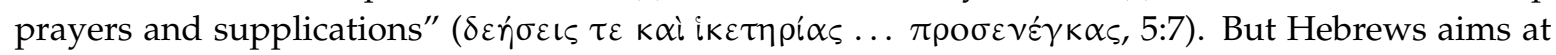
creatively changing the content of the metaphor. For the first time, it employs the term "sacrifice" with reference to the death of Jesus on the cross by fusing it with "blood" (7:27; 10:10, 12, 14). Hebrews thus alters and transcends traditional sacrificial metaphors to suggest that Christ accomplished salvation through his death (2:14). ${ }^{35}$ Based on this argument and these creative developments, we can assume

30 On scholarly theories regarding the meaning of sacrificial rituals in Second Temple Judaism see (Drexler 1993, pp. 1-2; Gerlitz 1995; McClymond 2008, pp. 3-17; Eberhart 2018, pp. 14-29). For summaries of the history of research on the theory of sacrifice from various perspectives, see (Milbank 1995; Eberhart 2017, pp. 2-12).

31 See also (Ullucci 2012, pp. 92-95).

32 Cf. (Lindars 1991, p. 420; Cortez 2006; Fuhrmann 2007; Karrer 2008, p. 147).

33 Cf. (Moffitt 2011; 2012, pp. 211-24).

34 Cf. (Eberhart 2011a; 2011b, pp. 17-32). Although the present essay focusses on cult metaphors in Heb 9, it is interesting to note that in later chapters, the dynamics of approach are still conveyed in, for instance, 12:18-24 according to which the

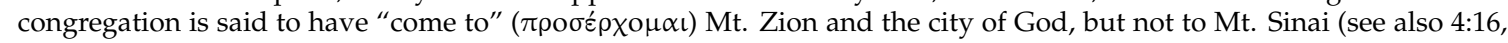
10:22). As Mary Ann Beavis and HyeRan Kim-Cragg note: "The first covenant, associated with Moses and Mount Sinai, is obviated by the new covenant, associated with the messiah, Jesus, and Mount Zion" (Beavis and Kim-Cragg 2015, p. 165). This difference is evoked by a different destination for pilgrims.

35 Cf. (Eberhart 2005, pp. 37-64; 2018, pp. 111-13). Due to the limited scope of the present essay we will not pursue other innovative features of sacrificial metaphors in Hebrews. For example, it has already been shown that the "transition from many to one priest implies a transition from many sacrifices to one" (Cortez 2006, p. 543 [italics original]). 
that the community which Hebrews addresses was in danger of returning to their previous faith and/or liturgical practices. Against such tendencies, Hebrews argues that the death of Christ is the pinnacle of salvation, superior to all previous religious concepts or programs such as the traditional Jewish temple cult.

A question that arises for the modern audience is how the perceived lack of tolerance of this kind of argument can be mitigated today. The core of the christological concept of Hebrews has, therefore, been called 'supersessionist.' Can modern theology reference soteriological imagery from Hebrews while remaining respectful to other religions, especially Judaism?

This question sheds a critical light on Hebrews 9. While Luther praised its author's theological creativity, he also noted that Hebrews contains a "hard knot," 36 something that cannot be accepted. For Luther this was the idea that there cannot be any repentance for sinners after baptism. This clashed with his understanding of justification by grace. Today we would add Hebrews' supersessionism as another unacceptable hard knot. As Luther noted, while the author of Hebrews built well, with "gold, silver, precious stones," there was also "wood, straw, or hay"37 mixed in too. Interpreters must attempt to separate the wheat from the chaff in this.

In order to do this, let us look again at Hebrews 9 as an example of theological creativity. Here, Jewish priestly and sacrificial images are used metaphorically to describe the saving significance of Jesus. Theological creativity cannot be reduced to linguistic creativity. It also involves the use of new background theories, as when Latin American liberation theology adopted the Marxist understanding of praxis intending social transformation as a conceptual framework and re-cast Christian theology as a critical theory. ${ }^{38}$ Hebrews has a distinctive background theory. It employs its metaphors against the backdrop of a cosmology that fuses Platonic and apocalyptic categories. ${ }^{39}$ However, what follows will focus on the novelty of the metaphors in Hebrews 9. Sufficient for this discussion is the theological creativity thereof.

A metaphor is a semantic innovation that responds "in a creative fashion to a question presented by things." ${ }^{\prime 4}$ The flagging devotion to Jesus in the community that Hebrews addressed raised questions to which the metaphors in Hebrews 9 responded. These metaphors use images of the temple priesthood and sacrifice to articulate the surpassing saving significance of Jesus' death and ascension. The use of these images extended the meaning of Jesus' death and ascension, boldly going where no other New Testament author had gone before. By virtue of their faith in Jesus' ascension to the right hand of God, the author(s) of Hebrews claimed that Jesus was a heavenly high priest and his death a heavenly sacrifice that fulfilled the need for atoning sacrifice once and for all, rendering all other sacrifice redundant. As noted earlier, this was an innovation in early Christian thought.

Earlier we noted that theological creativity must be faithful to its sources, lest it conflict with them. Hebrews was included in the New Testament canon because it was judged to be largely faithful to the church's memory of Jesus and what he meant. It extended this, but it did not depart from it. As a semantic innovation, a metaphor has to be appropriate to what it seeks to describe. Otherwise it will be dismissed as a category mistake. But a successful metaphor is both appropriate and creative in its description of something at the same time. Here we come to a paradox of language and theological creativity. In a successful metaphor the creation and revelation of meaning coincide. ${ }^{41}$ A metaphor creates what "it discovers; and what it finds, it invents." ${ }^{42}$ It creates a way of articulating a meaning that is discovered through a question presented by its context. In a given situation, "something seeks

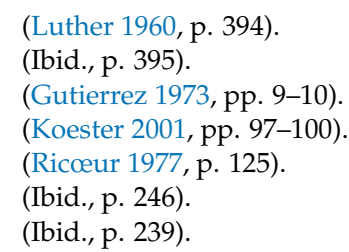


to be said, ${ }^{\prime 43}$ that exceeds what existing terms can articulate. In such a context theological creativity is required for the meaning of the gospel to be adequately expressed, and through the creative possibilities of language a new meaning of the gospel may come to light. Hebrews 9 is an example of this.

Broadly speaking, this kind of theological creativity has three sources. One is the challenge posed in a situation that reveals the limits of existing theological language. A second is an author's creativity, their sensitivity to what they are discussing and their ability to use words and images in a new way to describe it. This creativity generates meanings that seek to establish themselves in the marketplace of ideas as a way of understanding the world. A metaphoric representation like the description of Jesus and his death and ascension in Hebrews 9 is a performance. It seeks to articulate an understanding of reality that will structure and constitute a field of meaning that gives rise to new or renewed subject-positions and interests. ${ }^{44}$ The meaning thus presented moves into the world where it encounters and struggles with others. This is a first trajectory of theological creativity. It is along this line that we need to examine the question of Hebrews' supersessionism. There is always an ideological taint to every understanding of reality. ${ }^{45}$ Theological creativity does not escape this ambiguity of the human condition, that good and evil are always in conflict within us and intertwined in our thoughts and actions. There is inevitably some straw mixed in with the gold and jewels that we build with.

Theological and linguistic creativity also has a third source. It responds to something beyond itself. At the origin of the metaphorical process there is the "ontological vehemence" 46 of something seeking expression that existing vocabularies cannot adequately express. In responding to this lack, theological creativity seeks to be accepted by others because it "fits" 47 what it seeks to describe. This 'fit' is never final because theological discourse both describes what is there and evaluates it. In such discourse, reason takes "a largely hermeneutical turn; and this brings with it a certain endlessness, a resistance to completion, the impossibility of resting in some supposedly 'final' and unimprovable conclusion." 48 Because theological language is never final, to use it "is to be constantly encountering its limits," 49 thus experiencing the need for theological creativity. This is part of the church's pilgrim condition that Hebrews describes with its image of the church seeking a city that is yet to come (Heb 13:14).

The question of "fit" has a trajectory ad intra, towards that from which the impetus for new description comes. This question arises because "language enables us to grasp something as what it is, ${ }^{\prime 50}$ never with finality, but with greater or lesser adequacy. A theological description applies not simply to the use made of something, but to its defining features. ${ }^{51}$ This trajectory concerns the "intrinsic rightness" of a description. ${ }^{22}$ Does it fit what it describes? This is the trajectory along which the question of the appropriateness of Hebrews' description of Jesus as high priest lies.

There is a third trajectory to theological creativity. As it responds to something beyond itself it also shapes the lives of those who accept it as fitting. "A new expression reveals a new way of inhabiting the world." 53 Because "humans as self-interpreting animals are partly constituted by their own self-descriptions," these self-descriptions have existential import. ${ }^{54}$ Theological creativity can thus re-shape peoples' sense of what they are and need. Hebrews 9 articulates how in Christ's death and ascension, a new reality came into being that removed the need for people to offer sacrifices in order to be in right relationship to God and one another. The ambiguity and frailty of the human

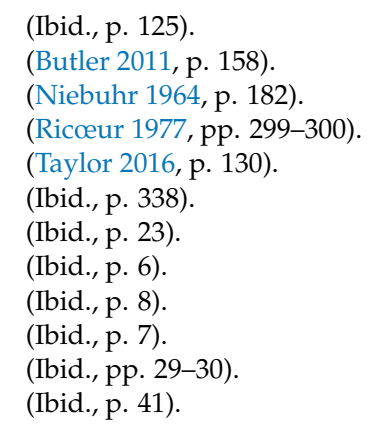


condition that gives rise to the need for sacrifice remains. But Hebrews 9 puts human life on a new footing in relation to this. It opens up in a new theoretical possibility: life without sacrifice. However, in doing so it emphasizes the saving significance of Jesus' death and ascension in a way that displaces Jesus' resurrection from central importance in its understanding of redemption. ${ }^{55}$

The ingenuity of the author(s) of Hebrews regarding the reconceptualization of sacrifice can indeed not be underestimated. ${ }^{56}$ Surprisingly, such inventiveness allows one to place Hebrews in the tradition of early Jewish thought-specifically with regard to what is sometimes called its supersessionism. Already the theology of the Hebrew Bible was not static but dynamic, moving forcefully ahead into hitherto unknown territory. This is manifest in, for instance, the "new covenant" that the prophet Jeremiah affirmed vis-à-vis the Mosaic covenant (Jer 31:31-34). Jeremiah spoke of God's law being written on human hearts, thus imagining an "internalization of the Mosaic covenant, when Israel would consistently obey Torah." ${ }^{57}$ The Septuagint version of this text (Jer 38:31-33LXX) is what the author(s) of Hebrews quoted and referenced repeatedly when construing renewal (Heb 8:8-12, with reprise in 8:13 and 10:15-17)..$^{58}$ This means that any allegation of 'supersessionism' against the concept of a "new covenant" in Hebrews would, therefore, also need to be applied to the "new covenant" of Jeremiah. So should Jeremiah's "new covenant" be labelled supersessionist? It could indeed be called that way, but with regard to the Mosaic covenant. In early Israel and Judah, covenants came to periodically succeed one another, and Jeremiah described yet a new stage in this ongoing process. He was no representative of a static but of a dynamic, creative covenantal theology. One Jewish covenant came to replace an older Jewish covenant, and therefore the prophet called it "new." Similar tendencies are attested in other sources from Second Temple Judaism, for example the Book of Jubilees and the Dead Sea Scrolls. ${ }^{59}$ By quoting Jer 38LXX at length, the author(s) of Hebrews embraced and articulated a similar type of creative and dynamic notion of covenant that comprehends life without sacrifice as a new possibility. Modern scholarly discussions of such theological dynamics would benefit from the insight that they are characteristic features within Judaism and as such imported into Hebrews. ${ }^{60}$ These dynamics have led not only Christianity to abandon the temple cult by transferring its main functionality to Jesus. Rabbinic Judaism has, in its own right, given up the temple cult, replacing it by the devotion and study of the Torah.

All this suggests that applying an un-nuanced notion of supersessionism to Hebrews may obscure more than it illuminates. This is the argument of Richard Hays, in a critique of his own earlier description of Hebrews as supersessionist. ${ }^{61}$ Hays argues that the New Covenantalism of Hebrews is "not supersessionist in the classic sense that it replaces one religious system with a new stable

\footnotetext{
(Perkins 1984, p. 245).

Cf. (Ullucci 2012, pp. 91-93).

(Beavis and Kim-Cragg 2015, p. 86).

58 It has been observed that this quotation is the most extended one in the entire New Testament; cf. (Fuhrmann 2007, p. 300). Comparing the MT Vorlage and its LXX rendition reveals that even the translator(s) of the book of Jeremiah approached their task with a considerable sense of creative license. Overall the Greek version of the book of Jeremiah as such features multiple adjustments intended to conform to the different cultural context of the Hellenistic Jewish diaspora community of Alexandria where the translation was produced; cf. (Vonach 2011, pp. 2696-814, 2723-31). In particular, Jer 31:33LXX

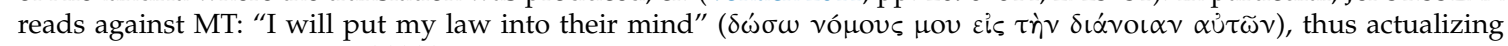
and explaining the Hebrew בקרבם for its Alexandrian audience (ibid., p. 2729). The author(s) of Hebrews quoted this adjusted version.

59 The book of Jubilees displays a characteristic construction of self-identity through a dynamic understanding of covenant. According to William K. Gilders, it "narrates the context of its own revelation as the making (or, rather, the remaking or renewal) of the covenant at Sinai" (Gilders 2012, p. 913). The early Jewish group at Qumran even considered itself the community of the renewed covenant. According to 1QS 10:10, the "covenant of God" was "entered" (i.e., affirmed) every morning and evening (ibid., p. 914). Both of these examples show the conceptual importance of covenant theology in Second Temple Judaism and the creativeness of its usage. By contrast, Philo shows a propensity to avoid the word "covenant" (e.g., in his Life of Moses or in Special Laws) or to redefine it from its original meaning.

60 As Mary Ann Beavis and HyeRan Kim-Cragg note: “The homilist is not arguing ... that 'Christianity' has replaced 'Judaism'” (Beavis and Kim-Cragg 2015, p. 87). We might add that it would be anachronistic to accuse the Prophet Jeremiah of a Christian agenda of supersessionism.

61 (Hays 2009). For his early comments, see (Hays 1989, pp. 98-99).
} 
religious system that allows readers to stand in a position of secure superiority." 62 Responding to Hays, Oskar Skarsuane observed that "early Christian supersessionism was no uniform, monolithic thing," and agreed that "many of the typical supersessonist motives are simply absent in Hebrews." 63 But Skarsuane disputes Hays' suggestion that the author of Hebrews would have been open to Israel continuing "to relate to God in the same way as they did before Christ, as though nothing had happened." ${ }^{64}$ Hebrews argues that the new covenant in Jesus Christ has made the former covenant old, obsolete, for Israel as well as others. ${ }^{65}$ This is starkly stated in Hebrews 8:13. ${ }^{66}$ Hebrews is supersessionist in arguing that henceforth this negates the validity and efficaciousness of Jewish sacrifice and priesthood. ${ }^{67}$

Can one employ Hebrews' metaphor of Jesus as heavenly high priest and still remain respectful of other religions, especially Judaism? Hebrews argues positively that Jesus is the heavenly high priest who entered the heavenly sanctuary "once and for all" having made a perfect sacrifice, thus effecting atonement. It argues negatively that the old covenant will pass away because it has been surpassed by the new. In the wake of the Holocaust this kind of Christian supersessionism was critiqued as dangerous to the Jewish people by Rosemary Radford Ruether in her book Faith and Fratricide. In his "Introduction" to this book, Gregory Baum noted the following:

The symbols of exclusivism belonging to a religion that has become culturally successful are objective factors that will affect the consciousness of a people and promote their cultural and/or political domination, a trend that no subjective factors, such as love and generosity, can overcome. A religion that has achieved cultural success, therefore, must be willing to submit itself to an ideological critique. ${ }^{6}$

Many Christian churches have since undertaken this kind of ideological critique and repudiated the idea that Christianity supersedes Judaism. ${ }^{69}$ However, Baum argued against relativizing the kind of positive claim made in Hebrews 9 altogether. ${ }^{70}$ A universally valid norm is needed to critique evil at home and abroad, and the struggle against evil requires a transcendent source of hope. Today, Christians can continue the claim of Hebrews 9 that Jesus has a transcendent saving significance, but in a way that repudiates its supersessionism and is respectful of Judaism and other religions. ${ }^{71}$ In terms of this trajectory, the problem lies not so much in the metaphors of Hebrews 9, but in its background theory which teaches that the old is surpassed and abolished unconditionally by the new. In many places today, Judaism and Christianity exist as dialogue partners, sometimes critiquing, sometimes affirming each other, but with an underlying solidarity of mutual respect amidst their differences. For many Christians today, this respect is rooted precisely in the claim that Jesus has transcendent saving significance. If Jesus reveals the truth, this truth must be honored wherever aspects of it are found. It is through dialogue with other religions like Judaism that a deeper understanding of this truth can be had. In arguing this, Christians today are faithful to the theological method followed by the author(s) of Hebrews. They "take up the basic kerygma"72 underlying Hebrews 9 and interpret it in light of questions and concerns arising from their context, just as Hebrews did, only using a different background theory.

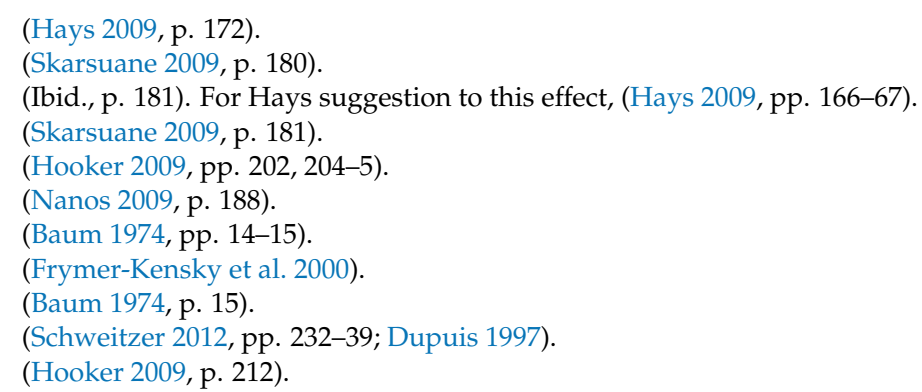


Does Hebrews' description of Jesus as high priest fit with what can be known about Jesus' ministry? Can it still be maintained if it is historically implausible? As mentioned above in footnote 27 , the gospels do not describe Jesus as a priest. A possible exception to this is the synoptic accounts of the Last Supper, in which Jesus could be said to assume a priestly role. But the historicity of this is uncertain..$^{73}$ Hebrews' description of Jesus as high priest is not historically accurate. However, the metaphors in Hebrews 9 are not concerned with historical accuracy. They divest themselves of concern with this "in order to reach the mythic level"74 where they disclose the transcendent meaning of Jesus' death and ascension. They function in spite of the contradiction between the literal truth of the images they use and what the gospels tell us of Jesus' ministry. A semantic clash between the literal referent of a term and its application to a new referent is intrinsic to metaphors. ${ }^{75}$ The meaning emerging from this clash is the solution to an enigma, ${ }^{76}$ how to speak of something that is beyond the range of existing terms of discourse. The similarities between the images of high priest and temple sacrifice and Jesus' person, death and ascension enable the former to describe the latter in spite of the differences between them. The ideas that Jesus' death had an expiatory saving significance and that the risen Christ intercedes for the church are found throughout the New Testament. The metaphors in Hebrews 9 take this further through graphic images that strain credulity as literal descriptions while expressing the finality of Jesus' saving significance on another level. These metaphors are linked through a discernible logic. Because Jesus is the heavenly high priest, he is able to offer the perfect sacrifice that inaugurates the new covenant in which sacrifices are no longer needed. The saving significance of Jesus' death and ascension were such that they demanded mythic expression. The combination here of "unconditioned reality communicating itself not only in conditioned form but in the ultimate conditionedness of death,"77 brings theologians "to a point where we can only gesture towards a discourse that we have no clear way of developing in the ordinary way ... ; to those kinds of representation that go outside the categories of imitation and reproduction." ${ }^{\prime 7}$ This is what the metaphors in Hebrews 9 do. They can be affirmed as meaningful if their lack of literal accuracy is acknowledged. Reading Hebrews 9 this way follows the approach of its author(s), who rejected "the literalist interpretation of the text without abandoning the text itself." 79 The fit between what the metaphors in Hebrews 9 say and what they describe does not lie on the level of historical description.

Finally, can Christians speak of the 'sacrifice of Christ' without putting violence and killing at the center of their redemptive vision? In arguing that sacrifice is no longer necessary Hebrews 9 focuses on the death of Jesus and re-interprets his ascension as a priestly act. What about his resurrection? An early and abiding meaning of Jesus' resurrection was his vindication by God. His ministry raised the question, who spoke for God? His crucifixion was intended to demonstrate that he did not. But Jesus' resurrection vindicated his ministry and led to his death, his ministry, and his person being re-interpreted. Included with his resurrection was his ascension, these two going together and supplementing each other, although sometimes appearing separately. The center of Christian faith is thus Jesus' ministry, his death, and his resurrection/ascension. Each of these is vital to the Christian message. If any one of these is missing, the remaining elements are liable to become distorted. Jesus' resurrection and ascension are central to the saving significance of Jesus in Hebrews $9 .^{80}$ His death does not achieve salvation by itself. His ascension to heaven is also required for this. ${ }^{81}$ But his resurrection is not explicitly mentioned, and his ascension is described in a way that focuses on his sacrificial death.

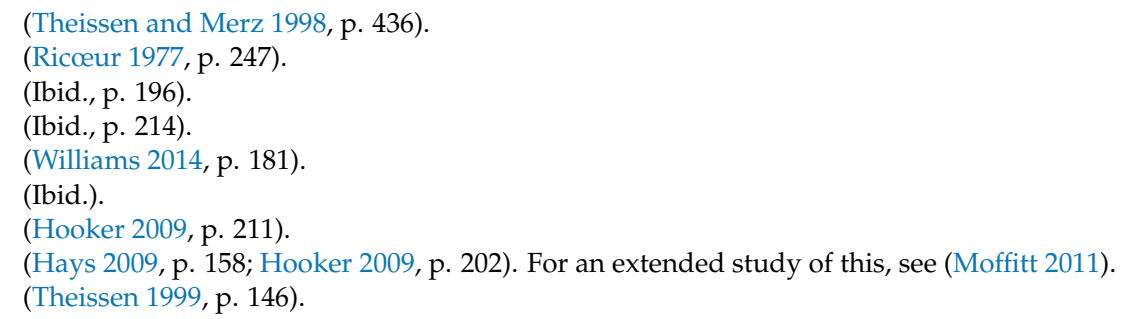


Jesus' resurrection dialogized his cross and ministry, so that these took on new and often contrasting meanings in early Christianity. His death was remembered as both a great sin, the murder of God's messiah, and as the means by which Jesus effected atonement for humanity. As is the case with "our narratives of ourselves and others," 82 it is impossible to reduce Jesus' death to one meaning or point of view. An understanding of Jesus' death as sacrificial expresses one of it meanings, but this alone cannot occupy the center of Christian faith. It always needs to be supplemented by an understanding of how his resurrection negated and overcame his death and brings a similar hope for the victims of history, and how it transformed his person so that he continues to be present in both history and eternity. Hebrews 9 contains the latter, but the former is not readily apparent. It was most likely Jesus' resurrection that was the catalyst for the new images employed in Hebrews $9 .{ }^{83}$ It was Jesus' resurrection that enabled early Christians to use sacrificial concepts to understand Jesus' death and to see it as ending the need to offer sacrifices. ${ }^{84}$ Christians can speak of the sacrifice of Christ and not put killing and violence at the center of their faith, if their understanding of Jesus' sacrifice is accompanied by an understanding of Jesus' resurrection as overcoming his death and promising an eschatological future in which death and violence are no more.

Hebrews 9 is an example of theological creativity, of how new images can be used to bring out the saving significance of Jesus in a conceptually striking way in relation to the cultural/religious background of a community. Its images are strange and potentially dangerous. Yet ultimately it is a humanizing discourse. It employs a barbaric concept, human sacrifice, but uses it to show how Jesus' death and ascension have ended the need for ritual sacrifices of any kind. By interpreting Jesus' death in light of his resurrection and ascension, as a priestly act that secures for people peace with God, it turns a barbaric act, the murder of an innocent victim, into a sign of love and hope that can empower solidarity and move others to seek justice and peace. By doing so, this theological creativity continues the reversal of Jesus' death that his resurrection began.

Author Contributions: Both authors were relatively equally involved at all stages of the research process and the writing of this paper, from initial hypothesis to design and deployment of the argument.

Funding: This research received no external funding.

Conflicts of Interest: The authors declare no conflict of interest.

\section{References}

Attridge, Harold W. 1989. The Epistle to the Hebrews: A Commentary on the Epistle to the Hebrews. Hermeneia. Philadelphia: Fortress Press.

Baum, Gregory. 1974. Introduction. In Faith and Fratricide. Edited by Rosemary Ruether. New York: The Seabury Press. Baum, Gregory. 1987. Theology and Society. New York and Mahwah: Paulist Press.

Beavis, Mary Ann, and HyeRan Kim-Cragg. 2015. Hebrews. Wisdom Commentary 54. Collegeville: Liturgical Press. Berger, Klaus. 1988. Hermeneutik des Neuen Testaments. Gütersloh: Gütersloher Verlagshaus Gerd Mohn.

Butler, Judith. 2011. Bodies That Matter. New York: Routledge. First published 1993.

Cortez, Felix. 2006. From the Holy to the Most Holy Place: The Period of Hebrews 9:6-10 and the Day of Atonement as a Metaphor of Transition. JBL 125: 528. [CrossRef]

Docherty, Susan. 2016. Recent Interpretation of Hebrews Chapters 3-4: Critical Issues and Scholarly Trends. ITQ 81: 385-89. [CrossRef]

Drexler, Josef. 1993. Die Illusion des Opfers: Ein wissenschaftlicher Überblick über die wichtigsten Opfertheorien ausgehend vom deleuzianischen Polyperspektivismusmodell. Münchener Ethnologische Abhandlungen 12. München: Anacon-Verlag.

Dupuis, Jacques. 1997. Toward a Christian Theology of Religious Pluralism. Maryknoll: Orbis Books.

82 (Williams 2014, p. 137).

83 (Perkins 1984, pp. 245-46).

84 (Theissen 1999, pp. 158-59). 
Eberhart, Christian A. 2005. Characteristics of Sacrificial Metaphors in Hebrews. In Hebrews: Contemporary Methods-New Insights. Edited by Gabriella Gelardini. BIS 75. Leiden and Boston: Brill.

Eberhart, Christian A. 2011a. Atonement. I. Hebrew Bible/Old Testament. EBR 3: 26-28.

Eberhart, Christian A. 2011b. Sacrifice? Holy Smokes! Reflections on Cult Terminology for Understanding Sacrifice in the Hebrew Bible. In Ritual and Metaphor: Sacrifice in the Bible. Edited by Christian A. Eberhart. SBLRBS 68. Atlanta: Society of Biblical Literature.

Eberhart, Christian A. 2017. Introduction: Constituents and Critique of Sacrifice, Cult, and Atonement in Early Judaism and Christianity. In Sacrifice, Cult, and Atonement in Early Judaism and Christianity: Constituents and Critique. Edited by Henrietta L. Wiley and Christian A. Eberhart. SBLRBS 85. Atlanta: SBL Press.

Eberhart, Christian A. 2018. The Sacrifice of Jesus: Understanding Atonement Biblically, 2nd ed. Eugene: Wipf \& Stock. Eco, Umberto. 1984. Metaphor. In Semiotics and the Philosophy of Language. Bloomington: Indiana University Press. Eisenbaum, Pamela M. 2005. Locating Hebrews within the Literary Landscape of Christian Origins. In Hebrews: Contemporary Methods_-New Insights. Edited by Gabriella Gelardini. BIS 75. Leiden and Boston: Brill.

Frey, Jörg. 2018. Die kultische Deutung des Todes Jesu. In » ... mein Blut für Euch«: Theologische Perspektiven zum Verständnis des Todes Jesu heute. Edited by Michael Hüttenhoff, Wolfgang Kraus and Karlo Meyer. BThS 38. Göttingen: Vandenhoeck \& Ruprecht.

Frymer-Kensky, Tikva, Peter W. Ochs, David Novak, David Sandmel, and Michael Singer. 2000. Christianity in Jewish Terms. Edited by Michael Singer, David Sandmel, Peter W. Ochs, David Novak and Tikva Frymer-Kensky. Boulder: Westview Press.

Fuhrmann, Sebastian. 2007. Failures Forgotten: The Soteriology in Hebrews Revisited in the Light of its Quotation in Jeremiah 38:31-34 [LXX]. Neot 41: 298.

Gerlitz, Peter. 1995. Opfer I. Religionsgeschichte. TRE 25: 253-54.

Gilders, William K. 2012. Covenant: IV. Judaism. EBR 5: 913.

Gutierrez, Gustavo. 1973. A Theology of Liberation. Maryknoll: Orbis Books.

Hall, Douglas John. 1989. Thinking the Faith. Minneapolis: Augsburg Fortress.

Hays, Richard. 1989. Echoes of Scripture in the Letters of Paul. New Haven: Yale University Press.

Hays, Richard. 2009. 'Here We Have No Lasting City': New Covenantalism in Hebrews. In The Epistle to the Hebrews and Christian Theology. Edited by Daniel Driver, Nathan MacDonald, Richard Bauckham and Trevor Hart. Grand Rapids: William B. Eerdmans Publishing Co.

Holtz, Gudrun. 2011. Pentateuchrezeption im Hebräerbrief. In Die Septuaginta und das frühe Christentum. Edited by Thomas S. Caulley and Hermann Lichtenberger. WUNT 277. Tübingen: Mohr Siebeck.

Hooker, Morna. 2009. Christ, the 'End' of the Cult. In The Epistle to the Hebrews and Christian Theology. Edited by Daniel Driver, Nathan MacDonald, Richard Bauckham and Trevor Hart. Grand Rapids: William B. Eerdmans Publishing Co.

Karrer, Martin. 2002. Der Brief an die Hebräer: Kapitel 1,1-5,10. ÖTK 20/1. Gütersloh: Gütersloher Verlagshaus. Karrer, Martin. 2008. Der Brief an die Hebräer: Kapitel 5,11-13,25. ÖTK 20/2. Gütersloh: Gütersloher Verlagshaus. Karrer, Martin. 2015. Hebrews, Epistle to the. EBR 11: 681.

Kaufman, Gordon. 1979. An Essay on Theological Method, rev. ed. Missoula: Scholars Press. First published 1975. Koester, Craig R. 2001. Hebrews: A New Translation with Introduction and Commentary. AncB 36. New York: Doubleday. Koosed, Jennifer L., and Robert P. Seesengood. 2005. Constructions and Collusions: The Making and Unmaking of Identity in Qoheleth and Hebrews. In Hebrews: Contemporary Methods-New Insights. Edited by Gabriella Gelardini. BIS 75. Leiden and Boston: Brill.

Kraus, Wolfgang. 2017. Wer soll das verstehen? Überlegungen zu den Adressaten des Hebräerbriefs: Ein Gespräch mit Udo Schnelle. In Spurensuche zur Einleitung in das Neue Testament: Eine Festschrift im Dialog mit Udo Schnelle. Edited by Michael Labahn. FRLANT 271. Göttingen: Vandenhoeck \& Ruprecht.

Lindars, Barnabas. 1991. Hebrews and the Second Temple. In Templum Amicitiae. Edited by William Horbury. JSNTSup 48. Sheffield: JSOT Press.

Lindbeck, George. 1984. The Nature of Doctrine. Philadelphia: The Westminster Press.

Luther, Martin. 1960. Luther's Works Vol. 35: Word and Sacrament. Edited by E. Theodore Bachmann. Philadelphia: Muhlenberg Press.

Marshall, Howard. 2009. Soteriology in Hebrews. In The Epistle to the Hebrews and Christian Theology. Edited by Daniel Driver, Nathan MacDonald, Richard Bauckham and Trevor Hart. Grand Rapids: William B. Eerdmans Publishing Co. 
Matera, Frank. 2007. New Testament Theology: Exploring Diversity and Unity. Louisville: Westminster John Knox Press. McClymond, Kathryn. 2008. Beyond Sacred Violence: A Comparative Study of Sacrifice. Baltimore: Johns Hopkins. Milbank, John. 1995. Stories of Sacrifice: From Wellhausen to Girard. Theory Culture Society 12: 15-46. [CrossRef] Moffitt, David M. 2011. Atonement and the Logic of Resurrection in the Epistle to the Hebrews. NovTSup 141. Boston: Brill. Moffitt, David M. 2012. Blood, Life, and Atonement: Reassessing Hebrews' Christological Appropriation of Yom Kippur. In The Day of Atonement: Its Interpretations in Early Jewish and Christian Traditions. Edited by Thomas Hieke and Tobias Nicklas. Themes in Biblical Narrative 15. Leiden: Brill.

Nanos, Mark. 2009. New or Renewed Covenantalism? A Response to Richard Hays. In The Epistle to the Hebrews and Christian Theology. Edited by Daniel Driver, Nathan MacDonald, Richard Bauckham and Trevor Hart. Grand Rapids: William B. Eerdmans Publishing Co.

Niebuhr, Reinhold. 1964. The Nature and Destiny of Man Volume 1: Human Nature. New York: Charles Scribner's Sons. First published 1941.

Perkins, Pheme. 1984. Resurrection. Garden City: Doubleday \& Company, Inc.

Ricœur, Paul. 1977. The Rule of Metaphor. Toronto: University of Toronto Press.

Rothschild, Clare K. 2009. Hebrews as Pseudepigraphon: The History and Significance of the Pauline Attribution of Hebrews. WUNT 235. Tübingen: Mohr Siebeck.

Schnelle, Udo. 2015. Die ersten 100 Jahre des Christentums 30-130 n.Chr.: Die Entstehungsgeschichte einer Weltreligion. UTB 4411. Göttingen: Vandenhoeck \& Ruprecht.

Schweitzer, Don. 2012. Jesus Christ for Contemporary Life. Eugene: Cascade Books.

Skarsuane, Oskar. 2009. Does the Letter to the Hebrews Articulate a Supersessionist Theology? A Response to Richard Hays. In The Epistle to the Hebrews and Christian Theology. Edited by Daniel Driver, Nathan MacDonald, Richard Bauckham and Trevor Hart. Grand Rapids: William B. Eerdmans Publishing Co.

Stegemann, Ekkehard W., and Wolfgang Stegemann. 2005. Does the Cultic Language in Hebrews Represent Sacrificial Metaphors? Reflections on Some Basic Problems. In Hebrews: Contemporary Methods—New Insights. Edited by Gabriella Gelardini. BIS 75. Leiden and Boston: Brill.

Taylor, Charles. 2016. The Language Animal. Cambridge: Harvard University Press.

Theissen, Gerd. 1999. The Religion of the Earliest Churches. Minneapolis: Fortress Press.

Theissen, Gerd, and Annette Merz. 1998. The Historical Jesus. Minneapolis: Fortress Press.

Thompson, James W. 2008. Hebrews. Paideia Commentaries on the New Testament. Grand Rapids: Baker Academic. Ullucci, Daniel C. 2012. The Christian Rejection of Animal Sacrifice. Oxford: Oxford University Press.

von Harnack, Adolf. 1900. Probabilia über die Adresse und den Verfasser des Hebräerbriefs. ZNW 1: 16-41. [CrossRef]

Vonach, Andreas. 2011. Jeremias: Ieremias/Jeremia. In Septuaginta Deutsch: Erklärungen und Kommentare zum griechischen Alten Testament, vol. 2: Psalmen bis Daniel. Edited by Martin Karrer and Wolfgang Kraus. Stuttgart: Deutsche Bibelgesellschaft.

Weiss, Hans-Friedrich. 1991. Der Brief an die Hebräer. KEK 13. Göttingen: Vandenhoeck \& Ruprecht.

Williams, Rowan. 2014. The Edge of Words. New York: Bloomsbury.

Zimmermann, Ruben. 2003. Paradigmen einer metaphorischen Christologie: Eine Leseanleitung. In Metaphorik und Christologie. Edited by Ruben Zimmermann, Jörg Frey and Jan Rohls. TBT 120. Berlin and New York: Walter de Gruyter.

(C) 2019 by the authors. Licensee MDPI, Basel, Switzerland. This article is an open access article distributed under the terms and conditions of the Creative Commons Attribution (CC BY) license (http:// creativecommons.org/licenses/by/4.0/). 